\title{
OBSERVATIONS ON THE ECOLOGY OF DRAGON-FLY NYMPHS: REACTIONS TO LIGHT AND CONTACT.*
}

\author{
By C. F. Curtis Riley.
}

I. Introductory.

CONTENTS.

II. Methods.

III. Responses in Natural Habitat.

VI. Enemies.

V. Food.

VI. Response to Intense Artificial Light.

VII. Movement Away from the Light Not a Response to Temperature.

VIII. Response to Contact.

IX. Formation of Groups.

$\mathrm{X}$. Inhibition of the Photic Response.

XI. Change of Bodily States.

XII. Disintegration of Groups.

XIII. Indefiniteness and Change of Photic Response.

XIV. Response to Less Intense Articfiial Light.

$\mathrm{XV}$. Response to Daylight.

XVI. Summary and Conclusion.

\section{INTRODUCTORY.}

The greater part of this work was completed several years ago. Publication has been delayed through various causes; chiefly because it had been the purpose of the writer to incorporate other experiments in the paper. The present communication is really an abstract of a more detailed piece of research which is practically completed, except for certain minor matters.

The research was undertaken at the suggestion of Professor S. J. Holmes. The writer desires at this point to express his appreciation of Doctor Holmes's kindly criticisms and also of his stimulating interest in the work of those associated with him. Thanks are also due to Doctor C. C. Adams for free access to his library and for many helpful suggestions.

The work was done upon certain forms of Agrionid nymphs. Many hundreds of different individuals were used in the experiments. It proved to be impracticable to identify the forms as the work progressed. A representative series of the nymphs were sent away for determination and, unfortunately, were lost in the mail. No essential differences have been found in the reactions of the different species, other than those of differences in degree, as evidenced in a few cases by relative inertness and activity.

* Contributions from the Zoölogical Laboratory of the University of I1linois, under the Direction of Henry B. Ward, No. 20. 
The insects were collected in the vicinity of Ann Arbor, Michigan, from various ponds, lakes, and marshy ground along the margins of streams. The Three Sister Lakes formed an excellent environment for collecting the nymphs. A large number of the organisms were taken in a pool, directly below the milldam, formed by the overflow of the Huron River, at Ann Arbor.

\section{METHODS.}

The experiments were performed in a dark room kept at a temperature of about $22^{\circ} \mathrm{C}$. The intense artificial light was from the electric arc of a Thomson projection lantern. For the weaker artificial light, a 16 c. p. electric incandescent light was used. Experiments were also performed with diffused daylight, its source being a south window $5 \mathrm{~m}$. distant from the dark room. The light entered through a small circular opening in the side of the dark room. The nymphs were placed in a glass trough with parallel sides which was half filled with tap-water. The trough was then placed on a table top, painted black. The table was so situated that the glass vessel lay in the beam of light, entering through the circular opening, with its long axis practically parallel with the rays of light.

\section{RESPONSES IN NATU'RAL HABITAT.}

In their natural habitat, Agrionid nymphs react strongly to contact. They are found clinging tightly to the stems, branches, and leaves of Elodea and Ceratophyllum. This is an indication of their decided thigmotactic proclivities. They tend to place as much as possible of the external parts of their bodies in contact with a solid surface. This is accomplished by clinging to the aquatic plants, in such a manner that the long axes of their bodies lie parallel to the long axes of the stems and the branches. The nymphs frequently assume a somewhat different position, with the long axes of their bodies rather oblique to the long axes of the stems and branches. The creatures are frequently found with their bodies closely applied to the Elodea and Ceratophyllum at the points where the branches are given offthat is, in the forks formed by the stem of the main plant and the lateral branches. They are also found on both plants in the angles formed by the whorls of leaves arranged around the stem. Pearl (1903, pp. 560-562) records similar observations in his work on Planarians. This writer has given the name 
goniotaxis to such responses. In an interesting paper on the death-feigning of Belostoma, Severin and Severin (1911a, p. 38) have described how this insect also reacts to the contact of aquatic vegetation.

The dragon-fly nymphs lie in wait for their prey on these aquatic plants. They are effectually concealed in such positions. The diameter of their bodies is about that of the thicker stems, and the creatures lie so quietly that they are easily overlooked. Then also their colors are much like those of the vegetation-browns and greens predominating. Facts of somewhat similar nature have been recorded by Holmes (1905, pp. 308-309) in his observations on Ranatra. In collecting the dragon-fly nymphs, the writer often rakes some of the plant material out of the water. The animals are then picked from the Elodea and Ceratophyllum. It is not at all an uncommon thing for many of them to be overlooked; because after the plants have been taken to the laboratory and placed in an aquarium jar containing water, the nymphs can be seen swimming about freely or resting on the bottom. Having been disturbed in transit, they frequently leave their positions on the aquatic vegetation. The reason that some of them are so easily overlooked is due to three facts. First, they remain very quietly in their positions - though some of them are seen crawling over the vegetation after it has been shaken from the net; second, their shape and color resembles that of the plants on which they live; and third, they frequently feign death. The writer believes that the instinct of death-feigning is of much importance in the ecology of the animal. It is a form of response which is certainly often highly protective. Many workers have frequently observed the death-feigning reaction among insects and to some extent the rôle which it plays in their lives. Among these observers may be mentioned the names of DeGeer, Fabre, Darwin (1884), Romanes (1884), and Whitman (1899). More recently papers by Holmes (1906) and Severin and Severin (1911a) have been written. Both of these deal with the death-feigning responses from a careful experimental point of view and are extremely valuable pieces of research. That the larvæ, nymphs, and imagoes of many aquatic insects evidence this interesting form of behavior is well brought out by these workers. This is especially the case in the paper by Severin and Severin (1911a, p. 36). 
Agrionid nymphs are found in quiet waters at a depth varying from $10-80 \mathrm{~cm}$. deep. So they live in an environment where the light is dim, a sort of twilight, certainly not a bright light. Then frequently there are reeds, sedges, cat-tails, pondlilies, arrowheads, and other aquatic plants which form shadows, so modifying the action of the sun's rays. It is not at all uncommon to find willows and alders shading the pools which serve as the living places for dragon-fly nymphs. The "selection" of such a habitat is influenced, to a considerable extent, by the natural responses of the animals. They react negatively to bright light and respond positively to contact. The laboratory experiments largely bear out these environmental observations.

\section{ENEMIES.}

Before considering the reactions of Agrionid nymphs to photic stimuli, it seems worth while to discuss briefly their food and enemies. While no extensive notes were taken on either of these subjects, yet some observations were recorded which indicate that the facts discussed in the last three paragraphs have a more or less direct bearing upon the relations of the nymphs to their food and enemies. In the states of Michigan and Minnesota, the two gamy little fishes, the common sun-fish, Lepomis gibbosus, and the yellow perch, Perca flavescens, are very abundant. Both of these species have frequently been taken by the writer in considerably numbers. It was often noticed that among other insects, found in the digestive tract, Odonate nymphs were present and many of them were Agrionid nymphs. It is very likely that Agrionid nymphs form a large portion of the diet of many other species of fish. In fact, Forbes (1888, pp. 485-524) found that the nymphs of Odonata formed a very important article of food in the case of the following fish: the common perch, Perca flavescens, the pirate perch, Aphredoderus sayanus, the crappie, Pomoxis annularis, and the grass pickerel, Esox vermiculatus. In the case of each of the three first named fishes, it was found that dragon-fly nymphs formed 10-13 per cent. of their food; and in the case of the grass pickerel, they formed 25 per cent. of the food. Needham (1898, p. 86) states that he has seen dragon-fly nymphs taken in numbers from the stomachs of the Great Blue and Green Herons. Aaron (Lamborn, 1890, p. 50) 
states that Ranatra, Notonecta, and Belostoma all prey upon the young nymphs of dragon-flies. From the context, one infers that Aaron's statement is based upon out-of-door observations.

Incidental observations were made upon the enemies of the dragon-fly nymphs when kept in confinement. In one aquarium, there were a number of the Agrionid nymphs and three Belostomas. In another aquarium, there were several of the nymphs and one Ranatra. It was found that both of these aquatic bugs preyed on the dragon-fly nymphs. At least three definite records were obtained with reference to Belostoma and two with reference to Ranatra. The nymph is seized by means of the first pair of legs - in the case of both Belostoma and Ranatra - and after the bug has placed its prey in a convenient positon, the "bill-like" mouth parts are pushed into the softer portions of the body, and the juices sucked out. Bueno (1903, p. 235) gives a good description of the method used by Ranatra in catching its prey. The behavior of Belostoma, when engaged in obtaining food is interestingly described by Severin and Severin (1911, pp. 101-102). Other naturalists have observed that many insects are enemies of dragon-fly nymphs while in confinement. Severin and Severin (1911, pp. 102-104) state that Belostoma and Nepa are both enemies of dragon-fly nymphs and prey upon them. Weed (1889, pp. 11-12) has noticed that in his aquaria the most important element of food of Belostoma, consisted of the nymphs of the larger dragon-flies.

FOOD.

The Agrionid nymphs are largely predaceous in their manner of feeding. They feed upon small Crustaceans and the nymphs of certain other small forms, particularly upon the nymphs of May-flies. It is a task of considerable difficulty and one requiring much patience to observe these organisms feeding in their natural habitat. The writer has observed, that in captivity, they feed upon each other, especially is this true, when the food supply is not abundant. Three dozen specimens were placed in an aquarium jar, no food being added, and at the end of three months there were two.nymphs alive in the jar. One can readily see the nymph in the very act of seizing its food, in an aquarium jar. The prey is seized by the lobes of the labium, this organ being thrust forward with great rapidity. The 
Agrionid nymphs usually remain obscured among the vegetation, where they seize the prey which approaches them. However, the writer has frequently observed them to move a distance of 30 or $40 \mathrm{~mm}$. toward their prey. The general movements remind one very much of those of a cat stealing upon a bird. The body crouches low, almost touching the substratum. The animal moves forward slowly, with bent legs, until it is close to its victim, then the lower lip is suddenly darted forward and the prey is captured. They will also feed upon freshly killed Physa, and small pieces of fresh beef.

Needham and Hart (1901, p. 17) make the following statement regarding the food of dragon-fly nymphs. "The nymphs are all predatory in habit. Most species remain in ambush, aided by coverings of sand, mud, silt, and algal growths, and by their own protective coloring, until their prey wanders within reach. Anax junius and a few others choose their prey. All capture it with a marvellously sudden extension of the labium, bringing it into the grasp of the formidable lateral lobes. Almost all kinds of small aquatic animals appear on the bill of fare of the group as a whole. The Agrionida have a seeming preference for Entomostraca and May-fly nymphs. The vegetation-inhabiting species have the most varied diet, including especially back-swimmers (Notonecta) and water-boatmen (Corisa), small crustaceans, such as Asellus and Allorchestes, thinshelled mollusks, like Physa, coleopterous and dipterous larvæ, and even the younger or weaker members of their own order. Anax takes even the thicker-shelled univalves, like Amnicola. The deep-water Epicordulia feeds principally on small mollusks, such as Amnicola and Physa, as well as on other life of the bottom. The Aeschnida, especially Anax, are most omnivorous creatures. The larger odonate nymphs eat very young fish, and in some cases appear to have caused a sweeping destruction of large numbers of them."

\section{RESPONSE TO INTENSE ARTIFICIAL LIGHT.}

There is a considerable amount of literature treating upon the photic responses of insects. The papers of Loeb (1905) are perhaps the most widely quoted. These have recently been translated and published. Little work has been done on the reactions of dragon-fly nymphs to light and contact. Plateau (1888) experimented with dragon-flies, but his observations are 
from a different viewpoint - "visual perception of movement"than that presented in the present paper. Further, Plateau's work was done with the imagoes and not with the nymphs. Some research has been carried on by Sondheim (1901) in connection with damsel-fly nymphs, regarding the power of associating certain appearances with food. Radl (1903) is the only author, of which the writer is aware, who has published any observations of this nature upon dragon-fly nymphs. Attention should also be called to the very interesting work of von Uexküll. One of his investigations in a series of Studies on Tonus was on the dragon-fly (1908).

Agrionid nymphs react strongly to the light from the electric arc of a Thomson projection lantern, swimming away from the source of illumination. Experiments were performed with separate individuals and also with a number of nymphs in the glass trough at the same time. After placing the vessel, containing the specimens, in the beam of light entering the dark room, it is seen that they swim away rapidly from the light to the far end of the dish-to the end farthest from the source of illumination. If the position of the trough is now reversedthe far end being placed in such a position that it is in the beam of light and facing its source - the creatures again swim away from the light. This experiment was repeated many times. Fresh nymphs were used from time to time.* At each experiment the animals swim away from the source of light and tend to congregate at the end of the glass trough most distant from the lantern.

MOVEMENT AWAY FROM THE LIGHT NOT A RESPONSE TO TEMPERATURE.

An observer of my experiments, who was at the time engaged upon some temperature studies of hydra, believed that the reactions described were responses to heat. That such was not the case was readily demonstated. A cell containing distilled water was placed in front of the projection lantern. The animals respond to the light in the manner previously stated and swim to the far end of the glass trough. A second cell was placed immediately in front of the first, so that the beam of

*The specimens were taken from aquaria standing in a moderate light at some distance from a south window. Such nymphs had not been subjected to the kind of stimuli used in the experiments. Of course, this does not mean that no stimuli had been acting upon them, for stimuli constantly impinge upon all animals. 
light now passed through a wall of water approximately $15 \mathrm{~cm}$. in thickness. My records show that, in a period of 30 minutes, the increase in temperature is very small. The dragon-fly nymphs react negatively to the light, as they did before either of the two cells were placed in position. This shows their movement to be a response to light, and not a reaction to temperature.

\section{RESPONSE TO CONTACT.}

When experiments are performed with a number of individuals in the glass trough, it is found that their movements are often very much modified. As they swim away from the source of illumination, they frequently come in contact with the sides of the vessel and with other individuals. This contact, in many instances, impedes the movement away from the light, and causes the nymphs to become practically motionless. This is the result of the contact stimulus. They usually assume a position with the long axes of their bodies parallel to each other and in close contact, although this relation may be modified considerably. Another response, which the writer designates as the "clasping response," quickly follows. The nymphs clasp each other closely around the thorax and abdomen. The preliminary contact of their bodies causes locomotion to cease, being an example of true thigmotaxis. Then as the full surface of the body of one is applied to the body of another the "clasping response" results.

\section{FORMATION OF GROUPS.}

The reactions above described often result in the formation of groups of nymphs. In this manner one large cluster may be formed, or a number of smaller ones. These collections may be formed at various points in the glass trough, but seldom at the end next to the source of light. They frequently form first at the end of the vessel farthest from the source of illumination. They may, however, form at other points nearer the light. As many as forty and fifty individuals, clinging together, are not infrequently counted in one cluster. The origin and permanence of the groups are due to the contact and clasping reactions. As various individuals swim away from the light, they may come in contact with other individuals, thus eliciting the thigmotactic response. Locomotion ceases and, as a greater bodily surface is applied in the case of the various nymphs, the "clasping response" is invoked, causing the creatures to hold each other tightly by means of their thoracic appendages. 


\section{INHIBITION OF PHOTIC RESPONSE.}

It is evident from the above observations that the reactions to light may be largely overcome by the response to contact. The efforts of the nymphs to swim away from the light are inhibited by thigmotaxis. The thigmotactic tendencies are evidenced by the organisms forming rather closely grouped aggregations. Various authors have called attention to somewhat similar facts. Formerly, comparatively little importance seems to have been attached to such observations, at least, among insects. More recently, however, certain workers have been impressed with phenomena of this nature. Holmes (1905, pp. 324-325) in his experiments with Ranatra has observed that, "The phototactic responses of Ranatra which usually occur with such regularity and precision are sometimes checked when the insect is engaged in performing some other function. **** Efforts to go toward the light are frequently inhibited by contact stimuli. When several individuals are put into a dish of water near a window they commonly cease, after a time, to swim towards the light and form a cluster in which they lie at all possible angles to the direction of the rays." The same writer $(1905$, p. 320$)$ also describes how Ranatras group themselves into "a dense bunch at the negative end "of the dish. Again, Holmes (1905, p. 323) while working with the same aquatic forms, states that, "In cool water there is a marked tendency to form a dense cluster in the negative end of the dish."' Severin and Severin (1911, pp. 100-101) in connection with some work on the thigmotactic responses of Belostoma flumineum Say make the following statement: "Again, it was not unusual to find two or more Belostomas or somewhat larger clusters clinging together at the surface or bottom of the water, a characteristic which is also noticed with Lethocerus (=Belostoma Aucct.) americanum, Benacus griseus, Nepa apiculata, Ranatra americana, and Ranatra kirkaldyi. This habit is probably a manisfestation of their thigmotactic response." This tendency to cluster together has frequently been observed by the writer in the case of Gerris remigis Say.

\section{CHANGES OF BODILY CONDITIONS.}

Much very valuable work has been done upon changes of bodily condition, especially among the Protozoa, as for example the researches of Putter (1900), Moore (1903), and particularly 
Jennings (1906, pp. 92-102). The following interesting quotation (pp. 92-94) is taken from the latter's observations upon Paramecia: "If the animal is at rest against a mass of vegetable matter or a bit of paper under the action of contact stimulus and it is then struck with the tip of a.glass rod, we find that at first it may not react to the latter stimulus at all. **** Finally a strong blow on the anterior end causes the animal to leave the solid and give the typical avoiding reaction. * * * * If specimens showing the contact reaction are heated, it is found that they do not react to the heat until a higher temperature is reached than that necessary to cause a definite reaction in free-swimming specimens. **** On the other hand, both heat and cold interfere with the contact reaction. Paramecia much above or below the usual temperature do not settle against solids with which they come in contact, but respond instead by a pronounced avoiding reaction. **** Specimens in contact with a solid react less readily to chemicals than do free specimens. $* * * *$ On the other hand, immersion in strong chemicals prevents the positive contact reaction * * ** * The contact reaction may completely prevent the reaction to gravity."

The inhibition of one stimulus by another is a somewhat puzzling matter. Why should a dragon-fly nymph reacting negatively to light, as it comes in contact with another nymph, cease this function and display its thigmotactic proclivities? The stimulus from the electric arc of a projection lantern is so strong that we might expect the organism to continue to react to the light rather than to respond to contact. However, this is not the case for the stimuli are sufficiently powerful to overcome the response to light. The explanation seems to lie with certain changes which take place within the animal. The external conditions are the same - the stimuli from the electric arc are still present - but the nymphs no longer react; the organisms now respond to contact stimuli. (However, some of the nymphs continue to react to the light.) 'One form of response gives way to another. This is probably due to certain changes in the bodily state of the organisms. We are unable to witness these changes as they occur within the animals themselves, but they can be inferred from the difference in the external response. Jennings (1904, p. 120), in connection with his discussion of the reactions of Stentors, has stated that, "We 
must conclude then that contact with solids so alters the physiological condition of the organisms that they no longer react to the other stimuli." This change in the internal condition of dragonfly nymphs must take place very rapidly, for as soon as an organism - that is swimming along under the influence of photic stimuli from the projection lantern-comes in contact with other nymphs, locomotion stops, and the animal responds to contact stimuli. If the electric arc should be turned off-thus doing away with photic stimuli - it would not be surprising to see the nymphs react in a different manner. Such a change is undoubtedly physiological, and must be largely explained by the new external stimuli acting upon the organism. Moreover, it may be possible that the stimuli from the electric arc have so modified the animal's internal condition that it responds to contact stimuli more readily than if it had not previously been subjected to photic influence. As Jennings (1906, p. 96) has well brought out in his work upon Paramecia, "The essential factor in the interference is a physiological one. When reacting to the contact stimulus, the animal is less easily affected by other stimuli, and when reacting to the other stimuli, it is less easily affected by the contact stimulus. Since the two stimuli in question require behavior of opposite character, it is indeed inevitable that one should give way to the other, or at least modify the behavior toward it; both cannot receive the usual reaction." Mast (1911, p. 287) in his discussion of "the effect of internal changes" makes the following interesting statement: "As a matter of fact, all reactions are directly controlled by internal forces which are in turn influenced by external factors." Jennings (1904, pp. 109-127) and (1906, pp. 283-313) has written full and elaborate discussions concerning "physiological states." Both of which are extremely interesting and suggestive.

\section{DISINTEGRATION OF GROUPS.}

Holmes (1905, p. 308) has found that Ranatras form a cluster in an aquarium. "In this way they may lie for hours in an almost motionless state." While somewhat similar conditions may be observed in the case of dragon-fly nymphs, the periods of quiet are very much shorter and the disintegration of the groups occurs from time to time. This is brought about by mechanical-contact-stimuli and response to the 
strong electric light. At irregular intervals the nymphs in the cluster make "spontaneous" movements - or at least movements that are often difficult to interpret from any external cause, though some of them may be due to the continued action of the electric arc - and such movements act as mechanical - contact-stimuli on other members of the group. This naturally tends to cause the animals to change their relative positions to some extent; and no matter how slight a change in position this may be, there is, for a short space of time, a slackening of the grip of the appendages. At such moments an opportunity is presented for photic stimuli to act upon the nymphs, and they frequently break away from the aggregation, responding with the negative reaction to light. This is more readily understood if realize that the organisms are probably in a different $p_{n}^{\text {f flysiological }}$ state than they were when the group was first formed - a state which now results in a response to the photic stimuli, and not to thigmotactic stimuli. The "spontaneous" or other slight movements of the animals in the closely packed masses are of great importance in initiating the breaking up of the clusters. Holmes (1095, p. 323) has observed in his experiments with Ranatra that the groups are more apt to be broken up as the insects become more active. The dragon-fly nymphs in the peripheral portion of the clusters are more likely to swim away first, while those in the central part are the last to leave the collections, as it is more difficult for the electric light to affect them in such a position. They are largely shut off from the light because of the nymphs surrounding them, besides being more largely influenced by contact stimuli. Holmes (1905, p. 308 ) states that in these clusters formed by Ranatra, the insects " are often so closely aggregated and so tangled together that those which are near the center of the group experience much difficulty in disengaging themselves."

We have noticed that dragon-fly nymphs respond negatively to photic stimuli. It has also been shown that they are positively thigmotactic. Their negative response to light often brings them against the sides of the experimentation dish and against each other. This contact invokes thigmotaxis, and the animals become grouped together. Mechanical - contactstimuli plus the influence of the strong electric light inhibits the contact reactions for the time being, and the aggregation is broken up, the organisms swimming away from each other in response to 
their phototactic proclivities. Later on the nymphs may again form a group which in turn will be dispersed. Observations very similar to these have been recorded by Holmes (1901, p. 212) upon Gammarus locusta. When these Crustaceans are exposed to light, they swim away from the Ceratophyllum, in the dish of water, to which they were clinging. They move rapidly to the negative end of the vessel, where they dart actively about, as if attempting to get farther away from the light. If these movements bring the animals in contact with the Ceratophyllum again, there they remain. If there are no objects in the water, the contact response is not invoked, and the organisms are found at the negative end of the dish. If trowe $\rightarrow$ r objects in the water, the Amphiopods react to contact stimuli enever their chance movements bring them against a solid suriace. The creatures remain in such a position until the phototactic impulse again causes them to swim away.

\section{INDEFINITENESS AND CHANGE OF PHOTIC RESPONSE.}

Sometimes, immediately following the breaking up of the aggregation of dragon-fly nymphs, the movements of the animals appear to lack definiteness. They swim away from the groups at various angles to the rays of light. While most of them sooner or later move toward the negative end of the glass trough, there are some whose reactions are indifferent, and a few evidence a tendency to positiveness in their responses to the light. This again the writer attributes to a change in the internal condition of the creatures, induced perhaps either by thigmotaxis or by the effect of the light from the projection lantern. Holmes (1905, pp. 318-325) has performed some very interesting experiments with Ranatra along similar lines. The insect is usually strongly positive in its responses to light; but this worker has been able to cause the animal to become negatively phototactic through the agency of contact stimuli. This change in the photic response, he was able to bring about many times. On one occasion the Ranatras were exposed to the light from a window for more than an hour and half, and it was found at the end of that time that all the specimens had become negatively phototactic. Previously they had all reacted positively to the light, yet they had become negative in their reactions although the intensity of the light had increased. He has also demonstrated that the negative phototaxis of these 
animals may be held in check by contact stimuli, as stated in the following quotation (1905, p. 325): "Contact stimuli not only inhibit positive phototaxis, but they produce a negative reaction as we have already seen; the latter tendency, however, is often held in check by the same cause by which it is brought about."

\section{RESPONSE TO LESS INTENSE ARTIFICIAL LIGHT.}

My experiments on dragon-fly nymphs with a 16 c. p. incandescent light show that the animals respond negatively, their movements taking them to the end of the glass trough farthest from the source of illumination. Frequently the organisms walk from one end of the vessel to the other in a rather leisurely fashion. In such cases the swimming mode of locomotion seems to be inhibited. The reactions are often lacking in promptness and precision as the following experiments will show:

Experiment $A$. The nymph is placed, by means of a camel's hair brush, in the glass trough facing the light. The creature is slightly nearer to the left than it is to the right side of the vessel. Immediately the animal turns slowly half way around. This movement is slow. Now, the anterior pair of legs come in contact with the side of the dish. It walks entirely onto the side of the trough. At the same time it continues the turning movement, until the head points away from the light. It walks slowly along the side for half the length of the vessel. The nymph stops for 5 seconds. Again it moves forward until within $4 \mathrm{~cm}$. of the end of the trough. It stops and performs cleaning reactions. In a few seconds, the animal walks slowly to the end of the trough.

Experiment B. The nymph is placed in the center of the glass dish, at the end near the source of light. It remains stationary for 7 seconds. The animal then turns slowly to the right until in a position oblique to the direction of the rays. It again remains quiet for 3 seconds. It turns slowly further to the right and at the same time moves slightly toward the right side of the vessel. The front legs come in contact with the glass side and the nymph stops for 4 seconds. The creature turns very slowly until it is in a position at right angles to the rays of light. As it turns, it walks slowly up the side of the dish. It remains here for 5 seconds in a position perpendicular to the floor of the trough. The animal turns slowly, the long axis of its body becoming parallel with the rays of light. It moves away from the light for a distance of $5 \mathrm{~cm}$. It then stops for 2 seconds. It again moves forward for a distance of $5 \mathrm{~cm}$. The nymph now stops for 3 seconds. It moves forward slowly for $2 \mathrm{~cm}$. It stops for 2 seconds and then goes ahead a distance of $4 \mathrm{~cm}$. The creature remains quiet for 3 seconds, after which it walks forward for $1 \mathrm{~cm}$. It again stops; this time for a period of 16 seconds and performs cleaning reactions. It then moves slowly to the end of 
the dish, passing the concave corner, and comes to rest at the end of the trough at right angles to the rays of light.

Experiment $C$. The nymph is placed in the glass dish at the end toward the light. It turns slowly toward the left until the body is at right angles to the rays of light. It remains in this position for 2 seconds. The animal turns further to the left. Its body is now oblique to the rays of light. It moves obliquely forward $1 \mathrm{~cm}$. The nymph turns to the left so that its body is now parallel with the rays of light. It swims forward $8 \mathrm{~cm}$. and then stops, resting on the bottom of the vessel. It remains stationary 6 seconds. Then it walks forward $4 \mathrm{~cm}$. It stops for 3 seconds with its body slightly oblique to the light rays. The animal walks forward $6 \mathrm{~cm}$. and then comes in contact with the side of the dish. It remains in a resting position for 25 seconds. It walks along the side of the vessel for $4 \mathrm{~cm}$. and then reaches the water. It walks forward for $2 \mathrm{~cm}$. and then stops, performing cleaning reactions. After remaining quiet for 20 seconds, it swims to the end of the dish.

The responses of the nymphs as indicated in these experiments are suggestive of those described by Holmes (1902, p. 212) for Gammarus and Amphithöe. This observer states that, "If a single individual be watched it will be seen to struggle for a time, to move away from the light; it will then rest, for a longer or shorter period, only to resume its struggle later." The writer performed a large number of experiments similar to those described as A, B, and C. In each case different nymphs were used. It is evident that such photic responses are conspicuously lacking in the factors of directness and precision. While the three experiments described are more or less similar in details, it is obvious that there are differences. The nymphs appear to possess some individuality. The movements are not so stereotyped, but that they allow of considerable modification.

A number of experiments were performed in which the same nymph was exposed to the light from the incandescent lamp. Usually there were ten trials in a series, and the same individual was used throughout each series. In referring to the details of my experiments, they indicate, in a general way at least, that in the first few trials of the series, the reactions to light were fairly definite - the animal moving away from the source of illumination. The animals frequently responded by the swimming movement. Toward the end of the series, there were more pauses as the organisms traveled from one end of the dish to the other. The cleaning reactions were performed from time to time as the nymph rested, and walking was the principal method of locomotion. 


\section{RESPONSES TO DAYLIGHT.}

Daylight was used as the source of stimulation for a large series of experiments. Many observations were recorded upon a great many different dragon-fly nymphs. In general it may be said that there was no evidence of orientation to the direction of the rays, and there seemed to be little indication of response to the light intensity, and the light was certainly brighter at the opening into the dark room than it was some distance away, within the dark room. The animals seemed to be generally indifferent to the light. At times, a few organisms indicated a tendency toward the positive reaction, but such facts are not uncommon in any experiments with light. Unless the dragonfly nymphs are nothing more than reflex machines, it is to be expected that there will be some physiological variation in the internal condition of the different individuals even under the effect of the same stimuli. There are usually a few animals which appear to vary in their responses from the majority at any given time.

\section{SUMMARY AND CONCLUSION.}

The Agrionid nymphs discussed in this paper were collected in the vicinity of Ann Arbor, Michigan. In their natural habitat they respond strongly to contact. They are frequently found clinging to Elodea and Ceratophyllum, and are generally in close contact with these plants. They are also found in the angles formed by the various parts of the plants. The nymphs are obscured in such positions because of certain resemblances in color and form between themselves and the plants to which they cling. These factors are probably protective, as is the death-feigning instinct which is so well developed in these insects. In the vicinity of Ann Arbor, Michigan, Agrionid nymphs were taken in abundance in still waters, at varying depths from $10-80 \mathrm{~cm}$. They are not generally found in bright light, but are more abundant in habitats shaded by aquatic vegetation and trees. The fact that they inhabit such situations is probably due to their negative response to strong light and to their positive response to contact. Two common enemies of these dragon-fly nymphs are the two species of fishes Lepomis gibbosus and Perca flavescens. The aquatic bugs Ranatra and Belostoma destroy large numbers of nymphs, when kept in confinement. Agrionid nymphs are 
predaceous insects. They feed upon small Crustaceans and the nymphs of May-flies. When kept in the aquarium, they prey upon each other. They also feed readily upon freshly killed Physa and small pieces of fresh beef. The nymphs usually wait for their prey to approach them before seizing it, but they may move a distance of $30-40 \mathrm{~mm}$. toward it. The food is seized by the lobes of the labium as this organ is suddenly darted toward the prey.

Agrionid nymphs respond negatively to the light from a Thompson projection lantern. They swim away from the source of illumination. This occurs both in the case of single individuals and also when a number of specimens are in a glass trough at the same time. If the position of the trough is reversed, the nymphs again swim away from the light. This sort of response continues even when the experiment is repeated a number of times. The movement away from the light is a photic response, and not a reaction to temperature. Frequently, when a number of specimens are placed in the glass trough, the response to light is modified by contact with the sides of the dish and with other individuals. This contact causes the nymphs to become more or less motionless, and to remain in close contact with each other, with their bodies more or less parallel. Such responses are examples of their thigmotactic proclivities. They also exhibit a "clasping response," seizing each other around the thorax and abdomen by means of their thoracic appendages. The thigmotactic and "clasping responses" result in the grouping of the nymphs in clusters. These groups tend to form at the end of the trough farthest from the source of light, although they also occur at other points. Sometimes there are as many as fifty individuals in a group. The origin and permanence of the groups are due to the contact and "clasping responses." The response of Agrionid nymphs to photic stimuli may be overcome by the response to contact stimuli; there is an inhibition of the one by the other. The explanation of this phenomenon seems to rest in part at least, with certain changes-bodily conditionswhich take place within the animal concerned. In many instances such changes probably occur rapidly. The clusters of nymphs break up from time to time. The disintegration seems to be due to several causes. The "spontaneous" movements of the insects in the groups are a factor in this. Such 
mechanical-contact-stimuli bring about changes in the relative positions of some of the individuals in the various groups. At such times there is a slackening of the grip of the appendages, so permitting photic stimuli to be more effective. The disintegration of the groups, then, is due to mechanicalcontact - stimuli plus the stimuli of the powerful electric light. Immediately after the disintegration of a group, there appears to be a lack of definiteness in the responses of the nymphs to the electric light. They swim away from the cluster at various angles to the rays of light. While the majority of them eventually arrive at the end of the trough farthest from the source of light, certain individuals exhibit a tendency to positiveness in their photic responses. This result may be due to a change in bodily condition, induced, possibly, either by thigmotaxis or by the effect of photic stimuli. Agrionid nymphs respond negatively to a 16 c. p. incandescent light, swimming away to the end of the trough farthest from the source of illumination. When responding to such photic stimuli, the insects frequently walk from one end of the trough to the other. The swimming reaction appears to be inhibited. The responses often lack promptness and precision. When the same individual is used in a series of experiments, the responses in the first few trials prove to be fairly definite, the animal swimming away from the source of illumination. Toward the end of the series there are pauses as the animal moves from one end of the trough to the other, and cleaning reactions are performed. When diffuse daylight is used as a source of illumination, the nymphs exhibit practically no response either to light intensity, or to the direction of the rays. A large majority of the insects appear indifferent to the light. A few individuals tend to exhibit a positive response to photic stimuli of this nature.

It seems possible to the writer that the behavior of Agrionid nymphs with respect to light and contact, may not be entirely of a reflex, mechanical nature. Such reactions are not always precise and definite; sometimes they are considerably modified. May they not, as Holmes (1905, pp. 337-349) has shown with respect to Ranatra, possess some of the concomitants of the "pleasure-pain" type of reaction? This form of response has been excellently discussed by Holmes (1910), (1911), and (1911a), in several suggestive papers. The thigmotactic and photic reactions of these dragon-fly nymphs appear to be bene- 
ficial. Such responses not only aid in concealment from enemies, but also assist in obtaining food. Beneficial reactions are frequently "pleasureable"; at least they are not usually "painful". On the other hand injurious responses are often "painful"; certainly they are not "pleasant". The nymphs are guided fairly well if they follow their "likes" and "dislikes", if such terms may be used. Spencer (1885) has maintained, and Holmes (1910) and (1911a) has discussed the probability that the connection between "pleasure" and "pain" has arisen through natural selection. If this should prove to be true with respect to other animal groups, there seems no reason why it should not apply to Agrionid nymphs.

\section{BIBLIOGRAPHY}

Aaron, C. B. 1890. The Dipterous Enemies of Man, pp. 23-68. New York. (An essay in Lamborn, R. H., Dragon-Flies vs. Mosquitoes.)

Bueno, J. R. de la Torre. 1903. Notes on the Stridulation and Habits of Ranatra fusca Pal. B. Canadian Entomologist, Vol. XXXV, pp. 235-237.

Darwin, C. 1884. A Posthumous Essay on Instinct, pp. 353-384. New York. (Appendix in Romanes, G. J. Mental Evolution in Animals.)

De Geer, C. 1752-1778. Memoires pour servir à 1'Histoire des Insectes. I-VII.

Fabre, J. H. 1879-1906? (Sixième-dixième série sans date.) Souvenirs Entomologiques Études sur 1'Instinct et les Moeurs des Insectes. 1re-10e. Série. Paris.

Forbes, S. A. 1888. On the Food Relations of Fresh-Water Fishes: A Summary and Discussion. Bulletin Illinois State Laboratory Natural History, Vol. II, Art. VIII, pp. $475-538$.

Holmes, S. J. 1901. Phototaxis in the Amphipoda. American Journal of Physiology, Vol. V, No. IV, pp. 211-234.

1905. The Reactions of Ranatra to Light. Journal of Comparative Neurology and Psychology, Vol. XV, No. 4, pp. 305-349.

1906. Death-Feigning in Ranatra. Journal of Comparative Neurology and Psychology. Vol. XVI, No. 3, pp. 200-216.

1910. Pleasure, Pain and the Beginnings of Intelligence. Journal of Comparative Neurology and Psychology; Vol. XX, No. 2, pp. 145-164.

1911. The Beginnings of Intelligence. Science, New Series, Vol. XXXIII, No. 848 , pp. $473-480$.

1911a. The Evolution of Animal Intelligence. 296, pp. New York.

Jennings, H. S. 1904. Contributions to the Study of the Behavior of Lower Organisms: Carnegie Institution of Washington, Publication 16. $256 \mathrm{pp}$. Washington.

1906. Behavior of the Lower Organisms. 366 pp. New York.

Loeb, J. 1905. Studies in General Physiology. Part I, 423 pp. Chicago

Mast, S. O. 1911. Light and the Behavior of Organisms. 410 pp. New York

Moore, A. 1903. Some Facts Concerning the Geotropic Gatherings of Paramecia. American Journal of Physiology. Vol. 9, pp. 238-244.

Needham, J. G. 1898. Birds vs. Dragon-flies. The Osprey, Vol. II, pp. 85-86.

Needham, J. G. and Hart, C. A. 1901. The Dragon-Flies (Odonata) of Illinois, Part 1. Petaluridæ, Aeschnidæ, and Gomphidæ. Bulletin Illinois State Laboratory of Natural History, Vol. VI, Art. 1, pp. 1-94. 
Pearl, R. 1903. The Movements and Reactions of Fresh-Water Planarians. A Study in Animal Behavior. Quarterly Journal of Microscopical Science, Vol. 46, pp. 509-714.

Plateau, F. 1888. Recherches expérimentales sur la vision chez les Arthropodes (cinquième partie). Bulletins de L'Académie Royale des Sciences, des Letteres et des Beaux-Arts de Belgique, cinquante-huitième année, 3me Serie, t. 16 , pp. $395-457$.

Putter, A. 1900. Studien über Thigmotaxis bei Protistein. Archiv für Anatomie and Physiologie, Physiologische Abteilung, Supplementband 1900, pp. 243-302.

Radl, E. 1903. Untersuchungen über den Phototropismus der Tiere. 188 pp. Leipzig.

Romanes, J. G. 1884. Mental Evolution in Animals. 411 pp. New York.

Severin, H. H. P., and Severin, H. C. 1911. Habits of Belostoma (=Zaitha) flumineum Say and Nepa apiculata Uhler, with Observations on other Closely Related Aquatic Hemiptera. Journal of the New York Entomological Society, Vol. XIX, No. 2, pp. 99-108.

1911a. An experimental Study of the Death-Feigning of Belostoma (=Zaitha Aucct.) flumineum Say and Nepa apiculata Uhler. Behavior Monographs, Vol. 1, No. 3, Serial No. 3, pp. 47. Cambridge.

Sondheim, M. 1901. Wahrnehmungsvermogen einer Libellenlarve. Biologisches Centralblatt, Bd. XXI, Nr. 1, pp. 317-319.

Spencer, H. 1885. Principles of Psychology. 2d ed. Vol. I, 642 pp. New York.

Uexkull, J. V. 1908. Studien uber den Tonus. V. Die Libellen. Zeitschrift für Biologie, Bd. L, pp. 168-202.

Weed, C. M. 1889. Studies in Pond Life. Bulletin Ohio Agricultural Experiment Station. Technical Series, Vol. I, No. 1, Art. II, pp. 4-17.

Whitman, C. O. 1889. Animal Behavior. Biological Lectures from the Marine Biological Laboratory. Wood's Holl, 1898, pp. 285-343. Boston.

Ecological Laboratory, University of Illinois, January 6, 1912. 


\section{$2 \mathrm{BHL}$ Biodiversity Heritage Library}

Riley, C F Curtis. 1912. "Observations on the Ecology of Dragon-Fly Nymphs: Reactions to Light and Contact." Annals of the Entomological Society of America 5, 273-292. https://doi.org/10.1093/aesa/5.3.273.

View This Item Online: https://www.biodiversitylibrary.org/item/43634

DOI: https://doi.org/10.1093/aesa/5.3.273

Permalink: https://www.biodiversitylibrary.org/partpdf/193601

\section{Holding Institution}

Smithsonian Libraries

\section{Sponsored by}

Smithsonian

\section{Copyright \& Reuse}

Copyright Status: NOT_IN_COPYRIGHT

This document was created from content at the Biodiversity Heritage Library, the world's largest open access digital library for biodiversity literature and archives. Visit BHL at https://www.biodiversitylibrary.org. 